\title{
Glorifying Indonesian Language through Online Learning
}

\author{
Oom Rohmah Syamsudin \\ \{omgeuliss@yahoo.fr\} \\ English Department, Postgraduate Program, Universitas Indraprasta PGRI, Jakarta, Indonesia
}

\begin{abstract}
The use of Indonesian language among young people lately tends to be cause for concern. This was a result of the freedom of language and expression exercised in social media. This article aims to describe efforts to re-enlighten the use of Indonesian through online learning using the Google Classroom and WhatsApp applications. By using a qualitative descriptive method, the researcher found non-compliance with Indonesian language rules in sentences used as written communication during online learning. The results showed that efforts to restore the use of Indonesian can be done starting from a limited environment, namely the environment of education. This effort can be done by regrowing the language attitude of students so that they can appreciate and preserve the Indonesian language, for example through giving prizes to students who already use Indonesian according to the rules and applying penalties for those who have not used it.
\end{abstract}

Keywords: Indonesian language, online learning, language attitude.

Memuliakan Kembali Bahasa Indonesia melalui Pembelajaran Daring

\begin{abstract}
Abstrak. Pemakaian bahasa Indonesia di kalangan muda akhir-akhir ini cenderung memprihatinkan. Ini merupakan akibat dari kebebasan berbahasa dan berekspresi yang dilakukan di media sosial. Artikel ini bertujuan untuk memaparkan upaya-upaya memuliakan kembali penggunaan bahasa Indonesia melalui pembelajaran daring dengan menggunakan aplikasi Google Classroom dan WhatsApp. Dengan menggunakan metode deskriptif kualitatif, peneliti menemukan adanya ketidakpatuhan terhadap kaidah bahasa Indonesia dalam kalimat-kalimat yang digunakan sebagai komunikasi tertulis selama pembelajaran daring. Hasil penelitian menunjukkan bahwa upaya mengembalikan penggunaan bahasa Indonesia dapat dilakukan mulai dari lingkungan terbatas, yaitu lingkup pendidikan. Upaya tersebut dapat dilakukan dengan menumbuhkan kembali sikap bahasa dari peserta didik agar bisa menghargai dan melestarikan bahasa Indonesia, misalnya melalui pemberian hadiah bagi siswa yang sudah menggunakan bahasa Indonesia sesuai kaidah dan menerapkan hukuman bagi mereka yang belum menggunakannya.
\end{abstract}

Kata kunci: bahasa Indonesia, pembelajaran daring, sikap bahasa. 


\section{Pendahuluan}

Pesatnya kemajuan teknologi di era millennium berdampak pada berbagai bidang, terutama yang saat ini tidak bisa dipisahkan dalam kehidupan sehari-hari adalah kemajuan dalam sistem informasi. Suatu peristiwa yang terjadi di suatu tempat di luar negeri, dengan mudah dapat diketahui dalam waktu yang sama melalui jalur internet. Terbukanya sistem informasi berdampak pula pada perkembangan gaya hidup, kesenian, kebudayaan, dan terutama pada penggunaan bahasa sehari-hari yang digunakan masyarakat, khususnya kaum millennial. Mengapa kaum millennial? Karena mereka lah saat ini yang terlihat sangat aktif menggunakan bahasa Indonesia secara lisan maupun tulisan, terutama dalam berkomunikasi di media sosial.

Salah satu bentuk komunikasi abad ini yang berkembang dengan pesat sebagai dampak kemajuan teknologi adalah penggunaan gadget atau gawai. Terlebih saat ini, pandemi Covid19 melanda seluruh dunia termasuk Indonesia, kebutuhan akan gawai semakin meningkat. Ketika semua warga disarankan untuk tinggal di rumah sebagai upaya memutus rantai penyebaran virus Corona, peran gawai menjadi semakin penting. Semua kegiatan yang bisa dilakukan dari rumah, dilaksanakan melalui pemakaian gawai, seperti pekerja kantoran melakukan Work from Home (WFH). Demikian juga dalam bidang pendidikan: sekolah, dari tingkat dasar hingga perguruan tinggi, juga dilakukan dari rumah. Kegiatan berbelanja secara daring, 'bersilaturahmi' dengan teman dan kerabat, semua dilakukan secara daring. Kegiatan komunikasi tersebut dilakukan dengan penggunaan berbagai aplikasi dalam media sosial, seperti Facebook, Instagram, WhatsApp, dan aplikasi lainnya.

Di tengah kemudahan yang bisa menunjang kegiatan sehari-hari melalui penggunaan teknologi mutakhir, tidak dipungkiri, ada 'kehilangan' yang cukup memprihatinkan. 'Kehilangan' itu adalah menurunnya penggunaan bahasa Indonesia, sesuai kaidah yang berlaku, dalam komunikasi melalui media sosial. Banyak temuan penelitian yang membuktikan bahwa media sosial sangat memengaruhi pengguna bahasa, khususnya di kalangan generasi muda, di antaranya adalah penelitian yang dilakukan oleh Retna Rahayu Widawati [1]. Ia melakukan penelitian pada siswa SMA Muhammadiyah 1 Yogyakarta. Ia menemukan bahwa telah terjadi perubahan pada penggunaan bahasa Indonesia di kalangan remaja yang ditandai dengan fenomena munculnya penggunaan bahasa alay dan mengontaminasi kebakuan bahasa Indonesia. Menurut penelitan tersebut, kontaminasi terjadi karena adanya pemberontakan dalam diri kalangan remaja terhadap tata bahasa. Selain itu, mereka juga menyukai penggunaan metafora, sindiran, dan bermain kata-kata dalam mengungkapkan pendapat mereka.

Penelitian lain yang dilakukan oleh Ira Maullin Octorina dkk, [2] menunjukkan adanya pengabaian dari kalangan remaja terhadap kaidah kebahasaan yang baik dan benar. Sementara itu, temuan menarik diperoleh Nurlina Rosida [3] yang melakukan penelitian terhadap penggunaan bahasa gaul siswa kelas XI di SMA Muhammadiyah 1 Makassar sebagai akibat dari pemakaian media sosial. Penelitiannya menunjukkan bahwa, secara positif, penggunaan bahasa gaul oleh para remaja mengindikasikan adanya kreativitas dan kepemilikan wawasan yang luas tentang gaya bahasa yang terus berkembang. Sisi negatifnya adalah penggunaan bahasa gaul mengganggu siapa pun yang membaca dan mendengar kata-kata yang digunakan dalam komunikasi mereka, karena tidak semua kalangan mengerti akan maksud dari kata-kata dalam bahasa gaul tersebut, sehingga sangat memusingkan dan memerlukan lebih banyak waktu untuk memahaminya. Berdasarkan penelitian-penelitian yang banyak dilakukan, dapat dikatakan bahwa media sosial sangat berpengaruh terhadap penggunaan bahasa Indonesia, 
seperti dalam tata bahasa, munculnya 'variasi' bahasa gaul, bahasa alay, yang secara tidak langsung juga menunjukkan tidak adanya kesantunan dalam berbahasa.

Seringnya seorang penutur menggunakan bahasa gaul, bahasa alay, atau bahasa Indonesia yang tidak sesuai kaidah, berpengaruh terhadap komunikasi "akademis" dalam dunia pendidikan. Misalnya, berkomunikasi dengan dosen/pengajar, seperti pada contoh berikut ini:

\section{“Ass bu ini jajang kls jumat regular kls p hardi sya ga bsa krm jawaban uts soalnya lgi mudik $g$ bsa internetan cianjur selatan kampung ua sya meninggal dunia bu”}

Tampak jelas dari contoh kalimat di atas, bahwa mahasiswa yang bersangkutan tidak memerhatikan kaidah bahasa Indonesia, seperti penggunaan huruf besar/kecil dalam kalimat, tidak ada pungtuasi, pemilihan diksi, dan penulisan singkatan yang tidak sesuai kaidah. Pembaca pesan di atas tentu agak kesulitan untuk memaknai kalimat, mengingat berbagai singkatan kata serta tidak ada pungtuasi/tanda baca. Selain itu juga tidak ada kesantunan dalam berbahasa. Selanjutnya ada pula contoh penggunaan bahasa dalam Instagram:

\section{@vegasibeng: "gue tuh literally lagi bosen dan butuh me time gitu guys cuma confuse perut gue sakit so im a little bit not well jd bingung kan akutuh?"}

Bila diperhatikan, dalam kalimat di atas, tidak ditemukan tanda baca, kecuali tanda tanya di akhir kalimat. Awal kalimat juga tidak menggunakan huruf besar, dan kata-kata dalam bahasa Inggris yang terdapat dalam suatu kalimat bahasa Indonesia pun tidak dicetak miring (Italic). Penulis kalimat di atas melakukan code mixing atau campur kode, namun tidak mengikuti kaidah kedua bahasa. Secara keseluruhan kalimat tersebut menyalahi, baik kaidah bahasa Indonesia maupun kaidah bahasa Inggris.

Menurunnya penggunaan bahasa Indonesia seolah mengindikasikan adanya pemerkosaan terhadap bahasa Indonesia dan menunjukkan telah terjadi "darurat bahasa" di Indonesia. Bila keadaan ini dibiarkan, tidak menutup kemungkinan akan berdampak pada kepunahan bahasa Indonesia, sebagai salah satu identitas bangsa dan negara Indonesia. Kenyataan tersebut menimbulkan pertanyaan penelitian: "Bagaimana memuliakan kembali bahasa Indonesia, khususnya bagi generasi muda?". Seperti diketahui, saat ini masa depan bahasa Indonesia juga terletak pada generasi muda Indonesia, yang dikenal juga dengan generasi millennial, dengan salah satu ciri yang "khas" adalah penggunaan bahasa Indonesia yang tidak mengikuti kaidahkaidah yang telah ditetapkan.

Mengembalikan kembali rasa hormat terhadap bahasa Indonesia, bukan hanya tugas pemerintah, tetapi merupakan tugas seluruh komponen bangsa, salah satunya dengan menumbuhkan kembali Sikap Bahasa (Language Attitude). Merujuk pada pendapat Kridalaksana [4], Sikap Bahasa adalah posisi mental atau perasaan baik terhadap bahasa sendiri maupun bahasa orang lain. Keadaan dan proses terbentuknya sikap bahasa tidak jauh berbeda dari keadaan dan proses terbentuknya sikap pada umumnya. Sebagaimana halnya dengan sikap, maka sikap bahasa juga merupakan peristiwa kejiwaan sehingga tidak dapat diamati secara langsung. Sikap bahasa dapat diamati melalui perilaku berbahasa atau perilaku tutur. Namun dalam hal ini juga berlaku ketentuan bahwa tidak setiap perilaku tutur mencerminkan sikap bahasa. Demikian pula sebaliknya, sikap bahasa tidak selamanya tercermin dalam perilaku tutur. Lunturnya sikap bahasa para generasi millennial terhadap bahasa Indonesia menunjukkan pula lunturnya kesantunan berbahasa dari para penuturnya. 
Ada pepatah mengatakan bahwa bahasa menunjukkan bangsa. Maksudnya, melalui bahasa yang digunakan dapat diketahui asal dari seseorang beserta budaya yang dibawanya. Bahasa juga dikatakan sebagai cerminan kepribadian seseorang. Cara berbahasa seseorang akan menjadi kebiasaan yang membentuk perilaku seseorang dan kemudian membentuk kepribadiannya. Orang Indonesia, sedapat mungkin harus berusaha untuk berbahasa Indonesia dengan baik, benar dan santun. Kesantunan, menurut Pranowo [5] merupakan wujud aktualisasi diri. Jadi, melalui pemakaian bahasa Indonesia yang benar dan santun, akan terjaga kehormatan dan martabat diri sendiri

Dalam menyikapi adanya "pemberontakan" dari generasi muda khususnya terhadap tata bahasa, sesuai temuan penelitian Retna Rahayu Widawati [1], dalam dunia pendidikan, para pengajar dapat mengingatkan kembali para pembelajar bahwa unsur-unsur tata bahasa seperti pungtuasi, pemilihan diksi, ejaan, merupakan hal yang sangat penting dan turut memengaruhi makna kalimat dalam berkomunikasi. Merujuk pada pendapat Gorys Keraf [6], bahasa terdiri dari 2 aspek, yaitu aspek bentuk dan aspek makna. Aspek bentuk dapat dibagi lagi menjadi 2, yaitu unsur segmental, yang meliputi fonem, morfem, kata, frasa, klausa, kalimat, dan wacana. Unsur lain dalam aspek bentuk adalah unsur suprasegmental, yang terdiri dari tekanan keras, tekanan tinggi (nada), tekanan panjang, atau intonasi. Saat ini di era komunikasi digital, unsur suprasegmental "dituliskan" melalui penggunaan emoticon.

Emoticon menurut Grannan [7] adalah tanda baca, huruf dan angka yang digunakan untuk membentuk sebuah tanda yang menggambarkan emosi atau perasaan. Emoticons are punctuation marks, letters, and numbers used to create pictorial icons that generally display an emotion or sentiment. (That's actually where the portmanteau "emoticon" comes from: emotional icon.) Oh, and because of the limits of our keyboard, most emoticons need to be read sideways. the smiley face :-) and the frowning face :-(. After this, emoticons were a big hit among Internet users. Emoticon misalnya :) atau :( dan banyak lagi.

Sejalan dengan kemajuan teknologi, setelah emoticon muncul pula tanda dalam komunikasi, khususnya internet, yaitu emoji. Emoji berasal dari bahasa Jepang " $e$ " yang berarti gambar dan "moji" yang berarti karakter. Emoji merupakan gambar/piktograf dari wajah, benda-benda, juga simbol. Selanjutnya, para pemakai internet yang dulu memakai emoticon yang hanya berupa tanda baca, huruf, dan angka, saat ini sudah menggunakan gambar emoji seperti contoh di bawah ini:

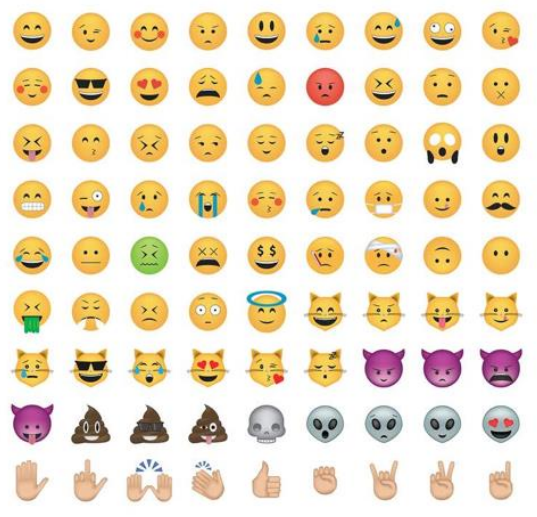

Gambar 1. Emoji dalam komunikasi di media sosial. 
Aspek suprasegmental dalam komunikasi, khususnya komunikasi yang menggunakan internet, saat ini bisa juga dilakukan dengan menggunakan emoji. Suatu penemuan yang dapat dikatakan positif karena akan lebih "memperjelas" unsur suprasegmental.

\section{Metode}

Penelitian ini dilakukan di Universitas Indraprasta PGRI Jakarta, pada masa perkuliahan daring semester genap 2019/2020. Pada semester tersebut, belum digunakan Learning Management System (LMS) untuk semua kegiatan pembelajaran di seluruh Program Studi di UNINDRA. Dosen dan mahasiswa masih mencari-cari aplikasi yang paling efektif untuk perkuliahan tatap muka, seperti Zoom, Google Meeting, Google Classroom, WhatsApp, Instagram, dan aplikasi lain yang memudahkan pengguna. Persiapan penelitian dimulai akhir bulan Maret, ketika perkuliahan daring dimulai karena pandemi Covid-19, sedangkan pelaksanaan pengambilan data selama 3 bulan, yaitu mulai akhir bulan April, Mei, Juni 2020.

Permasalahan penelitian dipecahkan menggunakan metode penelitian deskriptif kualitatif, yaitu metode yang dilakukan dengan langkah-langkah menyelidiki, menemukan, menggambarkan, dan menjelaskan kualitas atau keistimewaan dari pengaruh sosial. Mengacu pada pendapat Nazir [8], metode deskriptif merupakan suatu metode dalam meneliti status sekelompok manusia, suatu objek, suatu set kondisi, suatu sistem pemikiran ataupun suatu kelas peristiwa pada masa sekarang. Tujuan dari penelitian deskriptif ini adalah untuk membuat deskripsi, gambaran atau lukisan secara sistematis, faktual dan akurat mengenai fakta-fakta, sifat-sifat, serta hubungan antar fenomena yang diselidiki. Menggunakan metode deskriptif, akan digambarkan proses/upaya-upaya mengembalikan pemakaian bahasa Indonesia yang sesuai kaidah dalam komunikasi sehari-hari antara dosen dan mahasiswa. Mengingat banyaknya aplikasi yang dapat digunakan dalam proses pembelajaran daring, maka dalam penelitian ini, obyek yang dikaji adalah karakteristik bahasa Indonesia, berupa kalimatkalimat yang digunakan dalam komunikasi tertulis khususnya menggunakan Google Classroom, dan WhatsApp, pada Prodi Bahasa Inggris FPS Unindra, sebagai upaya mendorong mahasiswa untuk menggunakan kembali bahasa Indonesia yang baik dan benar. Berikut daftar mahasiswa yang menjadi responden dalam penelitian ini:

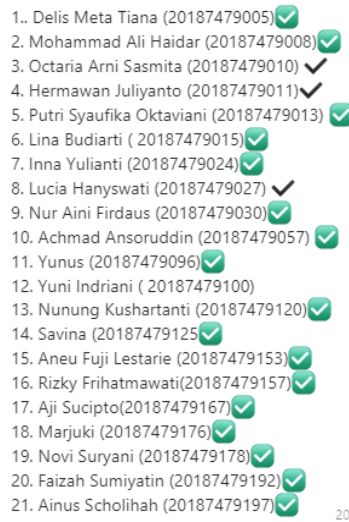

Gambar 2. Daftar Responden. 
Teknik pengumpulan data yang digunakan di antaranya adalah studi pustaka, berupa kajian teori-teori yang berhubungan dengan kebahasa-indonesiaan, seperti tata bahasa, makna bahasa, pemertahanan bahasa, sikap bahasa, campur kode maupun alih kode. Selain itu, juga dilakukan proses dokumentasi, dengan mengumpulkan foto-foto, lembaran peraturan, yang berhubungan dengan obyek penelitian, serta wawancara dengan nara sumber untuk memperoleh gambaran yang lengkap mengenai persepsi mereka atas pemakaian bahasa Indonesia khususnya di media sosial. Dalam penelitian ini juga digunakan instrumen penelitian berupa angket yang berisi kumpulan pertanyaan mengenai pendapat responden tentang penggunaan bahasa Indonesia di media sosial.

\section{Hasil dan Pembahasan}

Seperti telah dijelaskan pada bagian terdahulu, pelaksanaan perkuliahan secara daring di UNINDRA pada semester genap 2019/2020 belum terpusat pada suatu aplikasi tertentu. Dalam perkembangannya, dicoba untuk menggunakan LMS, suatu istilah global untuk sistem komputer dalam mengelola proses pembelajaran. LMS dapat digunakan untuk mendistribusikan materi perkuliahan, proses absensi, proses komunikasi antara dosen dengan mahasiswa, hingga proses evaluasi pembelajaran seperti quiz, ujian tengah semester, maupun ujian akhir semester. Seluruh petunjuk yang diberikan menggunakan bahasa Indonesia, dengan penekanan pada "gunakan bahasa Indonesia yang baik dan sopan". Sangat disayangkan, pelaksanaan LMS terkendala oleh sistem informasi yang belum begitu stabil, sehingga dalam pelaksanaan penelitian ini, data yang berupa komunikasi tertulis antara dosen dan mahasiswa, diperoleh dari pembelajaran dengan menggunakan Google Classroom dan WhatsApp. Secara keseluruhan, pada awal-awal perkuliahan, mahasiswa masih menggunakan bahasa "mereka", karena terbiasa berkomunikasi dalam media sosial. Berikut salah satu contoh komunikasi dalam grup WhatsApp:

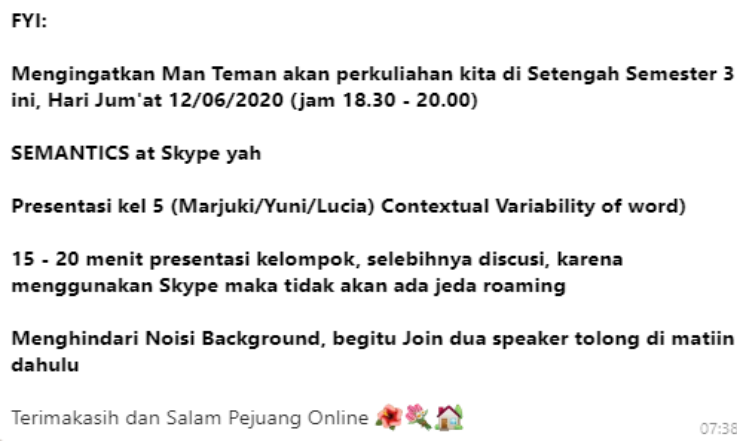

Gambar 3. Contoh komunikasi dalam grup Whatsapp.

Contoh di atas, terlihat menggunakan bahasa khas anak muda, salah satu tandanya adalah penggunaan campur kode (Code mixing), seperti pada kata-kata:

a. FYI (For your information)

b. "at" pada kalimat: "Semantics at Skype yah"

c. Discusi (seharusnya "diskusi” atau "discussion") 
d. Roaming (pada kata "jeda roaming")

e. Noisi (seharusnya "Noisy") Background

f. Join dua speaker

Informasi dalam pesan tersebut dapat dimengerti dan dianggap "biasa saja" oleh para penuturnya. Tetapi dari sisi kaidah bahasa Indonesia, kalimat-kalimat dalam pesan di atas, tidak mengikuti kaidah tata bahasa (tidak ada kata berakhiran -in, seperti pada kata "dimatiin"), tidak ada sapaan "Man...teman" dalam bahasa Indonesia standar, serta tidak menunjukkan kesantunan berbahasa.

Dosen kemudian memberikan penjelasan yang tentu sudah diketahui oleh mahasiswa, bahwa dalam lingkup perkuliahan, komunikasi harus menggunakan bahasa yang baik dan benar, walaupun terkesan kaku. Seharusnya mahasiswa sudah bisa menerapkan komunikasi dengan kaidah bahasa yang baik, mengingat bahasa Indonesia sudah dipelajari sejak di tingkat pendidikan paling rendah, tetapi tetap saja, ada pengabaian terhadap kaidah yang benar. Di sisi lain, komunikasi dengan menggunakan bahasa di media sosial, "membentuk" kelas baru, yang dikenal dengan sebutan "gaul1", dan mereka yang tidak mengikuti dikenal dengan "tidak gaul".

Proses memuliakan kembali bahasa Indonesia dalam suatu proses pembelajaran daring, sangat bisa dilakukan, jika dosen memiliki keinginan dan tanggung jawab untuk mengingatkan mahasiswa dalam pelestarian bahasa Indonesia. Dosen juga memiliki "kekuatan," salah satunya berupa "ancaman," untuk ditunjukkan kepada mahasiswa, misalnya akan mengurangi nilai yang diperoleh mahasiswa apabila dalam berkomunikasi dalam lingkup perkuliahan masih menggunakan bahasa Indonesia yang tidak baku. Bagaimanapun, "ancaman pengurangan nilai" masih ampuh, untuk menggiring mahasiswa ke arah lebih baik. Di bawah ini adalah contoh perbaikan komunikasi yang dilakukan oleh mahasiswa dari kelas yang sama setelah mendapatkan penjelasan mengenai kaidah bahasa Indonesia.

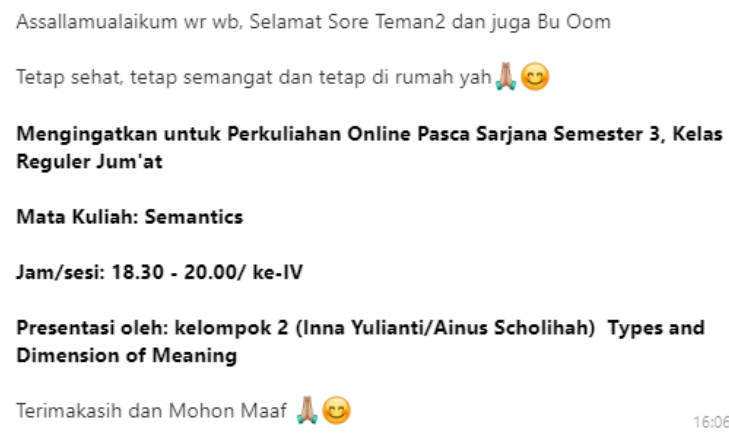

Gambar 4. Komunikasi dalam grup Whatsapp setelah mempelajari kaidah berbahasa Indonesia.

\footnotetext{
${ }^{1}$ Bahasa gaul [9]sebenarnya sudah ada sejak 1970-an [9]. Awalnya istilah-istilah dalam bahasa gaul itu untuk merahasiakan isi obrolan dalam komunitas tertentu. Tapi karena sering juga digunakan di luar komunitasnya, lama-lama istilah-istilah tersebut jadi bahasa sehari-hari. Jika anak-anak muda tidak menggunakan bahasa gaul ini, mereka akan merasa ketinggalan jaman, kuno, nggak gaul, dan sebagainya. Bahkan menurut kamus bahasa gaul sendiri, bergaul itu artinya supel, pandai berteman, nyambung diajak ngomong, periang, cerdas, dan serba tau info-info yang aktual, tajam dan terpercaya alias luwes wawasan. Sumber: http://polyglotindonesia.org/id/article/bahasa-gaul
} 
Contoh di atas, menunjukkan adanya perbaikan dari mahasiswa ke arah bahasa Indonesia yang lebih baik, lebih santun, walaupun masih belum sempurna. Dosen memang harus bersabar dalam mengarahkan mahasiswa, walaupun mereka sudah cukup dewasa bila dibandingkan dengan siswa SMA, namun perilaku kebahasaan yang menunjukkan kelas "gaul" nampaknya tetap dipetahankan. Berikut contoh lain yang juga ditulis oleh mahasiswa dari kelas yang sama:

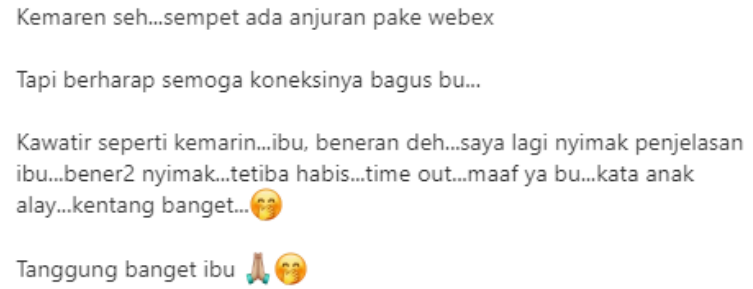

Gambar 5. Contoh komunikasi dalam grup Whatsapp.

Kalimat-kalimat di atas, bila dilihat, hampir sama dengan tulisan/kalimat yang berasal dari responden sebelumnya, dalam pemilihan diksi khususnya, mahasiswa masih menggunakan kata-kata yang tidak baku, seperti:

a. "Kemaren seh...." Merujuk pada kata "Kemarin sih...."

b. "tetiba habis...time out...." Merujuk pada kata "tiba-tiba habis..."

c. "kentang banget...." Merujuk pada kata "tanggung banget...."

Namun demikian, responden tersebut segera menyadari kekeliruannya dan segera memperbaiki bahasa komunikasinya, seperti pada kalimat di bawah ini:

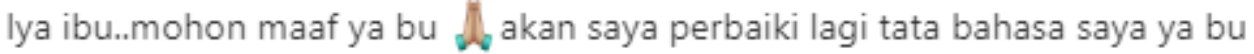

Gambar 6. Komunikasi dengan penggunaan tata bahasa Indonesia.

Selama masa pembelajaran daring yang tergolong "dadakan" karena tidak direncanakan sebelumnya, komunikasi antara dosen dan mahasiswa cenderung dilakukan secara tertulis/bertukar pesan melalui aplikasi WhatsApp. Untuk pertemuan tatap muka digunakan apikasi lain yang memungkinkan terjadinya komunikasi langsung, seperti Google Meet, Webex, Zoom, dan aplikasi lain yang dianggap mudah oleh mahasiswa. Berdasarkan wawancara, dari 21 responden, hampir semua menggunakan bahasa tidak baku dalam komunikasi tertulis sehari-hari, mereka juga mengakui kalau penggunaan bahasa Indonesia baku dalam percakapan akan cenderung 'serius' dan terkesan 'tua', kuno, tidak gaul. Dalam situasi seperti ini, peran dosen sebagai "wasit" sangat penting, dosen harus bisa berperan untuk menghentikan/"menarik" mahasiswa agar kembali ke dalam penggunaan bahasa Indonesia yang sesuai kaidah. Dosen juga diharapkan untuk tidak "hanyut" atau "turut serta" bersama mahasiswa menggunakan bahasa gaul dalam lingkup akademik, di luar itu, silahkan saja. Dosen juga dapat mengajak mahasiswa untuk membentuk 'Sikap Bahasa' terutama sikap hormat dan bangga mahasiswa terhadap bahasa Indonesia. Di sisi lain, penggunaan bahasa Indonesia yang sesuai dengan kaidah juga bermanfaat bagi mahasiswa ketika kelak mereka 
harus menuliskan laporan penelitian berbentuk tugas akhir seperti skripsi,thesis, karena tentu saja penulisan ilmiah harus menggunakan bahasa Indonesia standar.

\section{Simpulan}

Berdasarkan paparan di atas, dapat disimpulkan bahwa telah terjadi "pemerkosaan" terhadap bahasa Indonesia yang dilakukan khususnya oleh generasi muda yang dikenal dengan "kaum Millenial". "Pemerkosaan" ini terjadi melalui penciptaan kosa kata baru seiring dengan meningkatnya penggunaan media sosial oleh para penutur bahasa Indonesia. Cepat atau lambat, bahasa Indonesia baku akan berakhir dengan kepunahan. Untuk menghindari lenyapnya bahasa Indonesia karena tergantikan oleh bahasa gaul yang lebih diminati oleh kaum muda, perlu dilakukan gerakan memuliakan kembali bahasa Indonesia, membentuk kembali sikap bahasa para peserta didik/mahasiswa agar lebih mencintai dan melestarikan bahasa Indonesia, mengangkat kembali harkat dan derajat bahasa Indonesia dengan menggunakannya kembali sebagai alat komunikasi sehari-hari, diawali dalam lingkup pendidikan/akademis.

Memuliakan kembali bahasa Indonesia bisa dimulai dari lingkungan pendidikan. Para pengajar/guru diharapkan menuntun kembali peserta didiknya untuk menggunakan bahasa Indonesia baku dalam komunikasi tertulis melalui pembelajaran daring, seperti yang saat ini sedang berlangsung akibat mewabahnya virus Corona di hampir seluruh tempat di dunia. Para guru/dosen diharapkan dapat mengoreksi kesalahan berbahasa para peserta didik/mahasiswa, memberikan contoh berbahasa Indonesia yang baik, bila perlu menerapkan pola "hadiah dan hukuman". Siswa/mahasiswa yang sudah berbahasa Indonesia yang baik dan benar, diberikan "hadiah" misalnya pengurangan tugas/PR, dan siswa/mahasiswa yang belum menggunakan bahasa Indonesia standard dalam berkomunikasi diberikan "hukuman" berupa pengurangan nilai sedikit, misalnya. Selalu ada hikmah di setiap peristiwa, begitu orang bijak berkata. Di balik ganasnya pandemi Covid-19, diharapkan bahasa Indonesia kembali dihargai, dilestarikan, melalui penggunaannya yang sesuai dengan kaidah yang berlaku, khususnya oleh generasi muda sebagai penerus bangsa Indonesia.

\section{Referensi}

[1] Widawati RR. Pengaruh Media Sosial terhadap Kebiasaan Berbahasa 2018; 1.

[2] Octorina IM, Karwinati D, Aeni ES. Pengaruh Bahasa di Media Sosial bagi Kalangan Remaja. Parol J Pendidik Bhs Dan Sastra Indones 2018; 1(5).

[3] Nurlina R. Pengaruh Media Jejaring Sosial Terhadap Penggunaan Gaya Bahasa Gaul Pada Siswa Kelas XI SMA Muhammadiyah I Unismuh Makassar. Eprint UNM 2018.

[4] Kridalaksana H. Kamus Linguistik. Jakarta: Gramedia Pustaka Utama; 2001.

[5] Pranowo. Berbahasa Secara Santun. Yogyakarta: Pustaka Pelajar; 2010.

[6] Keraf G. Diksi dan Gaya Bahasa. Jakarta: Gramedia Pustaka Utama; 2008.

[7] Grannan C. No Title. Britannica n.d.

[8] Nazir M. Metode Penelitian. Jakarta: Ghalia Indonesia; 1988.

[9] Laurensius K. Bahasa Gaul. Polyglot Indones; 2014. 